\title{
THE DURATION AND DISAPPEARANCE OF PASSIVE DIPHTHERIC IMMUNITY.*†
}

HERBERT M. GOODMAN.

(From the Bacteriological Laboratory, The University of Chicago.)

The value of passive immunization with antitoxic serum for prophylaxis against diphtheria is now so well appreciated and its use for this purpose so widespread that information concerning the duration and extent of the protection thus conferred is of considerable practical, as well as scientific, importance.

The literature contains several clinical estimates of the approximate duration of this passive immunity. Thus, Rubens ${ }^{x}$ places it at about four weeks when a dose of 200 units is employed; Behring ${ }^{2}$ from observations made at Heubner's clinic gives a similar figure; Aaser ${ }^{3}$ estimates it at three to four weeks; $\mathrm{Maag}^{4}$ at five weeks; and Sittler ${ }^{5}$ at three to five weeks when the child is not exposed, and at Io to I4 days when in contact with diphtheria patients. Accurate determinations, however, have been limited to the persistence of antitoxin in the serum of injected animals. Passini ${ }^{6}$ found that after the injection of $2, \infty 00$ units into an adult man antitoxin could be demonstrated in the serum for II days, while following the injection of 200 units into a goat it could be detected only up to the third day. Mueller ${ }^{7}$ working on children found antitoxin present in their serum for from 6 to 37 days after administration, with no constancy. Neither of these investigators made quantitative determinations. Behring, however, after injecting 25,000 units into a goat made quantitative examinations of the amount of antitoxin in each cubic centimeter of serum and found that on the 23 day an appreciable quantity was still present, but did not continue his observations any farther. Kraus and Joachim ${ }^{8}$ tested the sera of rabbits and guinea-pigs at intervals of one and 24 hours after the

* Received for publication March 4,1908 .

$\dagger$ Read betore the Association for Advancement of Science, January, 1908, Chicago.

I Deulsche med. Wchnschr., 1895, 21, p. $758 . \quad 5$ Jahrb. f. Kinderheilk., I 1906, 44, p. 3.

$=$ Fortschr. d. Med., $1897,1_{5}$, p. I.

${ }_{3}$ Berl, klin. Wchnschr., 1905, 42, p. 38.

${ }^{\circ}$ Wien. klin. Wchnschr., 1896, 9, p. 111 .

${ }_{4}$ Jour. Am. Med. Assoc., roo6, 47, p. 158 (abstract).

7 Jahrb. f. Kinderheilk., I897, 44, p. 304.

${ }^{8}$ Wien. klin. Wchnschr., 1903, 16, p. 1389 . 
injection of antitoxin, but their results vary from 33 per cent to $9 \circ$ per cent and show no constancy. Bulloch ${ }^{1}$ injected 25,000 units subcutaneously into an ass and made a number of quantitative determinations at intervals of from 30 minutes to I 26 days. The maximum he found at 24 hours and the final disappearance did not occur until sometime between the rooth and $\mathrm{r} 26$ th days. J. H. Smith ${ }^{2}$ performed a similar experiment using a man as subject. He administered 9,000 units ( $5 \frac{1}{3}$ units per c.c. of blood serum) into the subcutaneous tissues and made a series of quantitative determinations of the serum, finding the maximum, reached on the third day, was less than one-fourth of the amount given, and that all trace of it was lost somewhere between the 2 th and 27 th days. Finally, Bomstein ${ }^{3}$ followed the disappearance of injected antitoxin from the blood of the dog and the guinea-pig, finding it entirely gone from the former in 18 days and from the latter in 22 days.

From the above it may be seen that not only have there been no attempts to gauge accurately the extent and duration of the immunity of the body as a whole, but that there is no information as to the relation exhibited between the amount of free antitoxin circulating in the blood stream and the extent of the immunity it affords the subject, and further, whether the disappearance of the somatic immunity (that is, the immunity of the body as a whole, as contrasted with that due to the blood) is synchronous with that of the antitoxin in the blood. It is scarcely necessary to dwell upon the practical value to preventive medicine of definite knowledge upon these points.

To obtain this information the extent of the somatic immunity and the amount of free antitoxin circulating in the blood were determined separately at each 24 -hour period in rabbits injected with diphtheria antitoxin. The rabbit was chosen for this investigation partly because no definite work had been previously done with it, but more especially because of its high degree of susceptibility to diphtheria toxin, as determined in a previous study. ${ }^{4}$ Gram for gram the susceptibility of the rabbit to diphtheria toxin introduced intraperitoneally is three times as great as that of the guinea-pig. Since but a small excess of

I Jour. Path. and Bact., 1898, 5, p. 274.

2 Jour. of Hyg., 1007, 7, p. 205.

${ }_{3}$ Centralbl. f. Bakt., 1897,22, p. 587 .

4 Goodman, Jour. Infect. Dis., 1907, 4, p. 509. 
toxin suffices to kill, the death of the animal affords a biological indicator of the neutral point in the toxin-antitoxin titration that is at once delicate and unambiguous. Intraperitoneal injections were employed exclusively with the rabbits, the advantage being that the animal is about three times as susceptible to this mode as to subcutaneous injection and equally as susceptible as to intravenous administration ${ }^{\mathrm{I}}$ while the intraperitoneal is more conveniently performed than the latter method, and finally the antitoxin is much more rapidly absorbed after intraperitoneal than after subcutaneous injection. ${ }^{2}$

To determine the curve of the general passive immunity, rabbits were injected with five units of antitoxin per kilo of body weight (o.I unit per gram of blood) and the amount of diphtheria toxin necessary to cause acute death in four or five days determined for each 24-hour interval until the immunity had fallen to the amount normal for the species. In this way the fraction of the original passive immunity persisting at each of these intervals was ascertained and was calculated in per cent of the original injection. In a few of the last stages a larger quantity of antitoxin than the above was necessary because of the minuteness of the fraction of the original amount persisting. The details of the experiment are shown in Table $\mathrm{I}$.

To determine the proportion of injected antitoxin persisting in the blood at each of these intervals, rabbits were injected with four units of antitoxin per gram of blood (estimating the blood as $\frac{1}{20}$ of the body weight according to Landois), and at the expiration of the period for which the test was intended the animal was bled, with aseptic precautions, from the ear vein or from the heart according to the amount of blood desired, into a sterile test-tube marked at the level of the desired volume of blood. The blood was then placed in the thermostat at $37^{\circ} \mathrm{C}$. for one hour to hasten coagulation, and after the serum had separated sufficient diphtheria toxin was added to neutralize the original content of antitoxin to the desired point, the mixture being made up to 5 c.c. with sterile salt solution if less than that volume, and injected subcutaneously into a guinea-pig without further standing since Morgenroth ${ }^{3}$ and Otto and Sachs ${ }^{4}$ have shown

I Goodman, Jour. Infect. Dis., I007, 4, p. 509.

a Smith, J. H., Jour. of Hyg., 1907, 7, p. 205.

3 Ztschr. f. Fyg., 1904, 48, p. 177; Berl. klin. Wchnschr., 1904, 4I, p. 526.

4 Ztschr. f. Exp. Path. u. Ther., 1906, 3, p. Ig. 
TABLE $\mathbf{~}$.

Decrease in Passive Immunity of Rahbit.

\begin{tabular}{|c|c|c|c|c|c|}
\hline $\begin{array}{c}\text { No. Days. } \\
\text { Interval be- } \\
\text { tween Injections }\end{array}$ & $\begin{array}{c}\text { Weight of } \\
\text { Rabbit }\end{array}$ & $\begin{array}{l}\text { Units Anti- } \\
\text { toxin Injected }\end{array}$ & $\begin{array}{l}\text { Guinea-Pig } \\
\text { M. L. D. } \\
\text { Toxin Given }\end{array}$ & $\begin{array}{c}\text { Percentage } \\
\text { Neutralization } \\
\text { of Antitoxin }\end{array}$ & $\begin{array}{c}\text { No. Days } \\
\text { Rabbit } \\
\text { Survived }\end{array}$ \\
\hline $1 \quad\{$ & $\begin{array}{l}2,080 \\
1,620 \\
1,850\end{array}$ & $\begin{array}{r}10.40 \\
8.10 \\
9.25\end{array}$ & $\begin{array}{l}520 . \\
270 . \\
231.25\end{array}$ & $\begin{array}{l}50 . \\
33.33 \\
25\end{array}$ & $4^{\frac{1}{2}}$ \\
\hline$=\{$ & $\begin{array}{l}2,220 \\
2,400 \\
2,030\end{array}$ & $\begin{array}{l}11.10 \\
12.00 \\
10.15\end{array}$ & $\begin{array}{l}370 . \\
384 . \\
304 \cdot 5\end{array}$ & $\begin{array}{l}33 \cdot 33 \\
32 . \\
30 .\end{array}$ & $\begin{array}{l}3 \frac{1}{2} \\
4\end{array}$ \\
\hline 3 & $\mathbf{I}, 955$ & $9 \cdot 78$ & 293.4 & 30. & 5 \\
\hline 4\{ & $\begin{array}{l}1,705 \\
1,490 \\
2,040\end{array}$ & $\begin{array}{r}8.52 \\
7.45 \\
10.20\end{array}$ & $\begin{array}{l}238.55 \\
\times 78.8 \\
204 .\end{array}$ & $\begin{array}{l}28 . \\
24 . \\
20 .\end{array}$ & $\begin{array}{l}2 \frac{1}{2} \\
4 \frac{1}{2} \\
7 \frac{1}{2}\end{array}$ \\
\hline 5$\}$ & $\begin{array}{l}1,330 \\
1,720 \\
2,140\end{array}$ & $\begin{array}{r}6.65 \\
8.60 \\
10.70\end{array}$ & $\begin{array}{l}123 . \\
137.6 \\
160.5\end{array}$ & $\begin{array}{l}20 . \\
16 . \\
15 .\end{array}$ & $\begin{array}{l}3 \\
4 \frac{1}{2} \\
5 \frac{1}{2}\end{array}$ \\
\hline 6\{ & $\begin{array}{l}\mathbf{1}, 660 \\
1,925\end{array}$ & $\begin{array}{l}8.30 \\
9.62\end{array}$ & $\begin{array}{l}\text { I24.5 } \\
\text { I34.70 }\end{array}$ & $\begin{array}{l}15 . \\
14 .\end{array}$ & $\frac{3 \frac{1}{2}}{5}$ \\
\hline $7 \quad\{$ & $\begin{array}{l}2,39 \circ \\
2,085\end{array}$ & $\begin{array}{l}11.95 \\
10.42\end{array}$ & $\begin{array}{l}\mathbf{1} 55.35 \\
\times 25.05\end{array}$ & $\begin{array}{l}\text { I3. } \\
\text { I2. }\end{array}$ & $4 \frac{1}{4}$ \\
\hline 8. \{ & $\begin{array}{l}\mathbf{1}, 535 \\
\mathbf{1}, 690 \\
\mathbf{I}, 710\end{array}$ & $\begin{array}{l}7.68 \\
8.45 \\
8.52\end{array}$ & $\begin{array}{l}84 \cdot 50 \\
84 \cdot 50 \\
76 \cdot 70\end{array}$ & $\begin{array}{l}\text { II. } \\
\text { IO. } \\
9 .\end{array}$ & $\begin{array}{l}3 \frac{1}{2} \\
3 \\
4 \frac{1}{2}\end{array}$ \\
\hline 9 & 2,080 & 10.40 & $83 \cdot 20$ & 8. & $4 \frac{1}{2}$ \\
\hline To \{ & $\begin{array}{l}2,105 \\
1,385\end{array}$ & $\begin{array}{r}10.52 \\
6.92\end{array}$ & $\begin{array}{l}84 \cdot 15 \\
48 \cdot 45\end{array}$ & $\begin{array}{l}8 . \\
7\end{array}$ & $4 \frac{1}{2}$ \\
\hline II \{ & $\begin{array}{l}I, 990 \\
2,200\end{array}$ & $\begin{array}{r}9.95 \\
\times 1.00\end{array}$ & $\begin{array}{l}74.65 \\
77.00\end{array}$ & $\begin{array}{l}7.5 \\
7.5\end{array}$ & $\stackrel{5}{+}$ \\
\hline $\begin{array}{l}12 \\
13\end{array}$ & $\begin{array}{l}1,680 \\
1,63^{\circ}\end{array}$ & $\begin{array}{l}8.40 \\
8.15\end{array}$ & $\begin{array}{l}58.8 \\
57.05\end{array}$ & $\begin{array}{l}7 . \\
6 \cdot 5\end{array}$ & $\begin{array}{l}5^{\frac{1}{4}} \\
4\end{array}$ \\
\hline 14\{ & $\begin{array}{l}1,275 \\
2,410 \\
x, 725\end{array}$ & $\begin{array}{r}6.38 \\
12.05 \\
8.62\end{array}$ & $\begin{array}{l}44 \cdot 65 \\
72 \cdot 30 \\
47 \cdot 40\end{array}$ & $\begin{array}{l}6 \cdot 5 \\
6.5 \\
5 \cdot 5\end{array}$ & $\begin{array}{l}2 \frac{1}{2} \\
3 \frac{3}{2} \\
4\end{array}$ \\
\hline I5 \{ & $\begin{array}{l}2,265 \\
2,330\end{array}$ & $\begin{array}{l}\text { II. } 32 \\
\text { II. } 65\end{array}$ & $\begin{array}{l}56.60 \\
46.60\end{array}$ & $\begin{array}{l}5 . \\
4 .\end{array}$ & $\begin{array}{l}3 \\
4 \frac{1}{2}\end{array}$ \\
\hline 16 & $\mathbf{I}, 800$ & 9.00 & 27. & 3. & 5 \\
\hline I \{ & $\begin{array}{l}x, 730 \\
2,085 \\
2,760\end{array}$ & $\begin{array}{r}8.65 \\
10.42 \\
13.80\end{array}$ & $\begin{array}{l}21.65 \\
22.00 \\
27.6\end{array}$ & $\begin{array}{l}2.5 \\
2.2 \\
2 .\end{array}$ & $\begin{array}{l}3 \frac{1}{2} \\
5 \\
7 \frac{1}{2}\end{array}$ \\
\hline 18\{ & $\begin{array}{l}\mathbf{r}, 890 \\
\mathbf{I}, 900\end{array}$ & $\begin{array}{l}9.45 \\
9 \cdot 50\end{array}$ & $\begin{array}{l}18.9 \\
17.1\end{array}$ & $\begin{array}{l}2 . \\
1.8\end{array}$ & $\begin{array}{l}3 \frac{4}{4} \\
4 \frac{1}{2}\end{array}$ \\
\hline I9 \{ & $\begin{array}{l}\mathbf{x}, 840 \\
\mathbf{I}, 720\end{array}$ & $\begin{array}{l}9.20 \\
8.60\end{array}$ & $\begin{array}{l}13.8 \\
\text { II.20 }\end{array}$ & $\begin{array}{l}\text { I. } 5 \\
\text { I. } 3\end{array}$ & $\begin{array}{l}3 \\
4\end{array}$ \\
\hline 20 & $I, 205$ & $12.05 \dagger$ & 12.05 & I. & 5 \\
\hline $21 \quad\{$ & $\begin{array}{l}I, 815 \\
I, 285\end{array}$ & $\begin{array}{l}16.15 t \\
\times 2.85 \dagger\end{array}$ & $\begin{array}{r}14.55 \\
8.95\end{array}$ & $\begin{array}{l}0.8 \\
0.7\end{array}$ & $\begin{array}{l}3 \\
4 \frac{1}{2}\end{array}$ \\
\hline $22 \quad 1$ & $\begin{array}{l}I, 560 \\
I, 605\end{array}$ & $\begin{array}{l}15.60 t \\
16.05 t\end{array}$ & $\begin{array}{l}9.30 \\
8.00\end{array}$ & $\begin{array}{l}0.6 \\
0.5\end{array}$ & $\stackrel{2}{5 \frac{1}{2}}$ \\
\hline 23\{ & $\begin{array}{l}I, \mathrm{~T} 30 \\
\mathrm{I}, 285\end{array}$ & $\begin{array}{l}22.60+ \\
25.70+\end{array}$ & $\begin{array}{l}0.05 \\
6.40\end{array}$ & $\begin{array}{l}0.4 \\
0.25\end{array}$ & $4^{2 \frac{1}{2}}$ \\
\hline 24 & $x, 310$ & 26.207 & $2.60^{*}$ & 0.1 & $t$ \\
\hline
\end{tabular}

* - more than the intraperitoneal M. L. D. †Double quantities. ‡Quadruple quantities. 


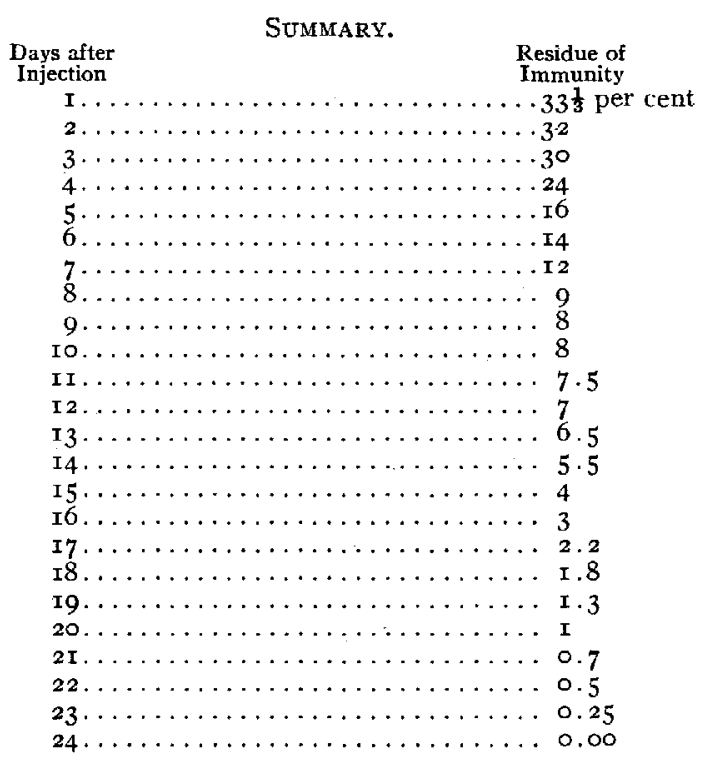

this to be unnecessary in the case of subcutaneous injections of toxinantitoxin mixtures. Death of the guinea-pig on the fourth or fifth day was taken to indicate exact neutralization of the antitoxin and therefore showing the amount thereof still in the blood. The abovedescribed method of collecting the blood was devised in order to obviate the necessity of making correction calculations for the ratio of serum to normal blood (practically none of the antitoxin is in the formed elements of the blood according to Dzerjgowsky, ${ }^{\mathrm{I}}$ since by this method all the serum obtainable from the given amount of blood was collected and it is quite inconsequential, so far as the accuracy of the experiment is concerned, whether I c.c. of blood yields $\frac{2}{3}$ c.c. of serum (Jörgensen and Madsen) or only $\frac{1}{2}$ c.c. of serum (Kraus and Joachim) or an inconstant quastity. In Table 2 are shown the minutiae of this experiment.

The results of the two experiments are recorded graphically in Chart $\mathrm{r}$. It will be seen that the fall in the passive immunity is quite rapid, during the initial two or three days comparatively gradual, but very abrupt during the ensuing week, the final disappearance being prolonged disproportionately and not occurring for some $3 \frac{1}{2}$

1 Acad. des Sci. Biol. de St. Pet., 1897, 5, p. r23. 
TABLE 2.

Amount of Free Antitoxin IN Blood.

\begin{tabular}{|c|c|c|c|c|c|c|}
\hline $\begin{array}{c}\text { No. Days } \\
\text { Interval } \\
\text { before } \\
\text { iBleeding }\end{array}$ & $\begin{array}{c}\text { Weight of } \\
\text { Rabbit }\end{array}$ & $\begin{array}{c}\text { Units Anti- } \\
\text { toxin } \\
\text { Injected }\end{array}$ & $\begin{array}{c}\text { Cubic Centi- } \\
\text { meters } \\
\text { Rabbit's Blood } \\
\text { Used }\end{array}$ & $\begin{array}{l}\text { Guinea-pig } \\
\text { M. L D. } \\
\text { Toxin } \\
\text { Injected }\end{array}$ & $\begin{array}{c}\text { Percentage } \\
\text { Neutralization } \\
\text { of } \\
\text { Antitoxin }\end{array}$ & $\begin{array}{l}\text { No. Days } \\
\text { Guinea-pig } \\
\text { Survived }\end{array}$ \\
\hline I $\}$ & $\begin{array}{l}2,200 \\
x, 680 \\
1,810\end{array}$ & $\begin{array}{l}440 \\
336 \\
362\end{array}$ & $\begin{array}{l}0.05 \\
0.05 \\
0.05\end{array}$ & $\begin{array}{r}10.0 \\
5.0 \\
4.0\end{array}$ & $\begin{array}{l}50 \\
25 \\
20\end{array}$ & $\begin{array}{l}1 \frac{1}{2} \\
1 \frac{1}{12} \\
4 \frac{1}{2}\end{array}$ \\
\hline 2\{ & $\begin{array}{l}1,495 \\
1,840\end{array}$ & $\begin{array}{l}299 \\
368\end{array}$ & $\begin{array}{l}0.05 \\
0.05\end{array}$ & $\begin{array}{l}4.0 \\
3.9\end{array}$ & $\begin{array}{l}20 \\
19 \cdot 5\end{array}$ & $\begin{array}{l}3 \frac{1}{2} \\
4 \frac{1}{2}\end{array}$ \\
\hline\{ & $\begin{array}{l}2,320 \\
2,170\end{array}$ & $\begin{array}{l}464 \\
434\end{array}$ & $\begin{array}{l}0.05 \\
0.05\end{array}$ & $\begin{array}{l}3.8 \\
3.6\end{array}$ & $\begin{array}{l}19 \\
18\end{array}$ & $\begin{array}{l}3 \\
4\end{array}$ \\
\hline 3 & $\begin{array}{l}1,905 \\
1,290 \\
1,660\end{array}$ & $\begin{array}{l}381 \\
258 \\
332\end{array}$ & $\begin{array}{l}0.05 \\
0.05 \\
0.05\end{array}$ & $\begin{array}{l}3 \cdot 4 \\
3 \cdot 2 \\
3 \cdot 0\end{array}$ & $\begin{array}{l}\text { I } 7 \\
\text { I6 } \\
\text { I5 }\end{array}$ & $\begin{array}{l}2 \frac{1}{2} \\
4 \frac{2}{2} \\
6 \frac{1}{2}\end{array}$ \\
\hline\{ & $\begin{array}{l}1,710 \\
2440 \\
2,225\end{array}$ & $\begin{array}{l}342 \\
488 \\
445\end{array}$ & $\begin{array}{l}0.05 \\
0.1 \\
0.05\end{array}$ & $\begin{array}{l}3.0 \\
5.0 \\
2.0\end{array}$ & $\begin{array}{l}\text { I5 } \\
\text { I2. } 5 \\
\text { I0 }\end{array}$ & $\begin{array}{l}I \frac{1}{2} \\
5 \\
6 \frac{1}{2}\end{array}$ \\
\hline\{ & $\begin{array}{l}1,700 \\
2,15^{\circ}\end{array}$ & $\begin{array}{l}340 \\
430^{\circ}\end{array}$ & $\begin{array}{l}0.05 \\
0.1\end{array}$ & $\begin{array}{l}2.0 \\
3.6\end{array}$ & $\begin{array}{l}\text { to } \\
9\end{array}$ & $\begin{array}{l}3 \frac{1}{2} \\
4\end{array}$ \\
\hline\{ & $\begin{array}{l}2,080 \\
2,200 \\
2,110\end{array}$ & $\begin{array}{l}416 \\
440 \\
422\end{array}$ & $\begin{array}{l}0.1 \\
0.1 \\
0.25\end{array}$ & $\begin{array}{l}3.6 \\
2.0 \\
4.0\end{array}$ & $\begin{array}{l}9 \\
5 \\
4\end{array}$ & $\begin{array}{l}1 \frac{1}{2} \\
4 \frac{1}{2} \\
6 \frac{1}{2}\end{array}$ \\
\hline 8 & 1,770 & 354 & 0.3 & 3.6 & 3 & 4 \\
\hline\{ & $\begin{array}{l}\mathbf{1}, 960 \\
1,800 \\
\mathbf{1}, 410\end{array}$ & $\begin{array}{l}392 \\
360 \\
282\end{array}$ & $\begin{array}{l}0.25 \\
0.5 \\
0.5\end{array}$ & $\begin{array}{l}2.0 \\
3.4 \\
3.0\end{array}$ & $\begin{array}{l}2 \\
1 \cdot 7 \\
1 \cdot 5\end{array}$ & $\begin{array}{l}3 \\
5 \\
5 \frac{1}{2}\end{array}$ \\
\hline\{ & $\begin{array}{l}1,640 \\
2,080\end{array}$ & $\begin{array}{l}328 \\
416\end{array}$ & $\begin{array}{l}0.5 \\
0.5\end{array}$ & $\begin{array}{l}3.0 \\
2.6\end{array}$ & $\begin{array}{l}\mathbf{I} \cdot 5 \\
\mathbf{I} \cdot \mathbf{3}\end{array}$ & $\begin{array}{l}3 \\
4 \frac{1}{2}\end{array}$ \\
\hline II & $\begin{array}{l}2,120 \\
2,020\end{array}$ & $\begin{array}{l}424 \\
404\end{array}$ & $\begin{array}{l}0.5 \\
0.55\end{array}$ & $\begin{array}{l}2.4 \\
2.0\end{array}$ & $\begin{array}{l}i .2 \\
0.9\end{array}$ & $\begin{array}{l}2 \frac{1}{2} \\
5 \frac{1}{4}\end{array}$ \\
\hline 12 & $\begin{array}{l}1,670 \\
1,755 \\
2,265\end{array}$ & $\begin{array}{l}334 \\
35 \mathrm{r} \\
453\end{array}$ & $\begin{array}{l}I .44 \\
I .00 \\
I .25\end{array}$ & $\begin{array}{l}4.0 \\
2 . \\
2 .\end{array}$ & $\begin{array}{l}0.7 \\
0.5 \\
0.4\end{array}$ & $\begin{array}{l}3 \frac{1}{2} \\
2 \frac{1}{2} \\
4 \frac{1}{2}\end{array}$ \\
\hline 3 & $\begin{array}{l}1,950 \\
1,770 \\
1,290\end{array}$ & $\begin{array}{l}360 \\
354 \\
258\end{array}$ & $\begin{array}{l}x .67 \\
2.5 \\
5 .\end{array}$ & $\begin{array}{l}2 . \\
2 . \\
2 .\end{array}$ & $\begin{array}{l}0.3 \\
0.2 \\
0.1\end{array}$ & $\begin{array}{l}2 \frac{7}{2} \\
2 \frac{1}{2} \\
5 \frac{1}{2}\end{array}$ \\
\hline 14 & $\begin{array}{l}1,400 \\
1,970 \\
1,550\end{array}$ & $\begin{array}{l}280 \\
394 \\
620\end{array}$ & $\begin{array}{l}5 \cdot 5 \\
10\end{array}$ & $\begin{array}{l}2 . \\
1 \\
2\end{array}$ & $\begin{array}{l}0.1 \\
0.05 \\
0.025\end{array}$ & $\begin{array}{c}2 \\
4 \frac{7}{2} * \\
16 ?\end{array}$ \\
\hline 15 & 1,380 & 552 & so $t$ & 2 & 0.025 & I2? \\
\hline
\end{tabular}

* Ulcer.

Double quantity of antitoxin used.

SUMMary.

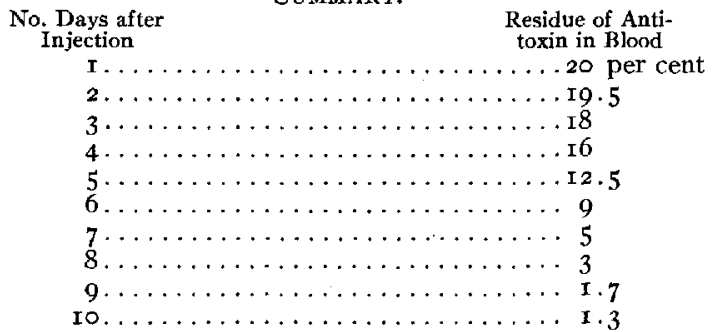




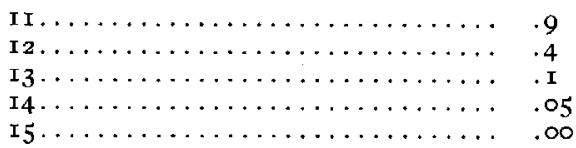

weeks. The fall in the antitoxin content of the blood is similar in general to that in the body protection, but presents two significant points of difference. In the first place it will be observed that relatively to the amount of antitoxin administered the general immunity

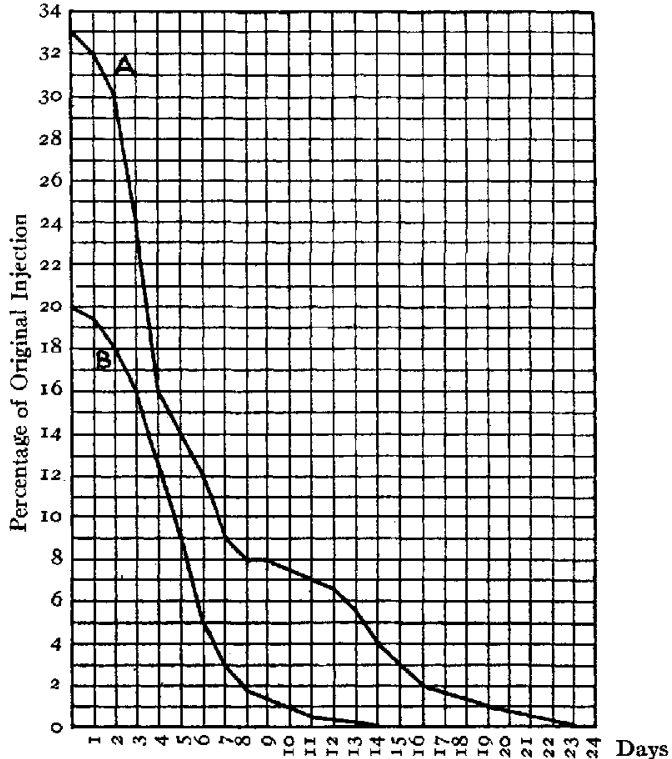

Chart r.-A, Somatic Immunity; B, Antitoxin in Blood. is always appreciably higher than the quantity of antitoxin free in the blood would lead one to expect, and in the second place the former persists considerably longer than the latter (nine days). The importance of these points is that they show that the amount of antitoxin circulating in the blood does not fullygauge the degree of protection conferred by an injection of the protective serum, the latter always being higher, the difference ranging, in terms of the quantity administered, from $I_{3}$ per cent on the first to 3.5 per cent on the fifth day, and secondly they show that the subject has a fair degree of protection for some time after all detectable antitoxin has disappeared from the blood.

It is of interest, at this point, to compare the foregoing results with those that others have obtained for the rabbit with tetanus antitoxin. Ransom ${ }^{x}$ and $\mathrm{Knorr}^{2}$ made quantitative determinations of the antitoxin content of the blood at several periods during the sojourn of tetanus antitoxin in the rabbit, and have constructed curves

\footnotetext{
I Jour. Path. and Bact, I900, 6, p. I80.

Quoted by Ransom.
} 
illustrating the hemic immunity. As is to be expected in the case of so different a substance, these curves differ in their details from Curve B, Chart $\mathrm{r}$, but they nevertheless correspond to it in general character, and may therefore be regarded as in a way confirmatory of the general accuracy of the results obtained here with the diphtheria antitoxin. Tizzoni and Catani ${ }^{\mathrm{I}}$ also have studied the persistence of tetanus antitoxin in the rabbit, using antisera obtained from the horse, dog, and rabbit. When that of the horse was used, no trace of the antitoxin remained after 15 days, which by an interesting coincidence is the exact duration of diphtheria antitoxin in the rabbit, as established above.

The obvious explanation of the discrepancy between the results shown in Table I and those in Table 2 would be that there occurs a storing-up of some of the injected antitoxin by the body tissues. The literature, however, appears to argue against such a view. Both Behring from observations made upon the goat and Bulloch from studies on the ass consider that almost all the antitoxin rapidly enters the serum as they found most of it there a few hours after the injection; Kraus and Joachim observed that the organs of normal rabbits have no power to combine with diphtheria antitoxin in vitro, and Bomstein states that in immunized guinea-pigs the organs contain either no antitoxin or no more than can be accounted for by their blood content. Kraus and Eisenberg ${ }^{2}$ and Kraus and Joachim have shown that diphtheria antitoxin is capable of producing no antibody to itself. Careful consideration of these points, however, must fail to convince that the above-mentioned hypothesis is thereby excluded, since, as far as the data of Behring and of Bulloch are concerned, it might well be that the serotropism is but a preliminary phenomenon and that after accumulating in the serum a part of the antitoxin passes thence into the tissues. Further, the observations of Kraus and Joachim by no means exclude the possibility that such a storing-up of the antitoxin does occur in the living body, and finally Bomstein's report, although apparently ruling out such a process, is far from being clear or definite. While giving no experimental data on the point, he states that the liver, lungs, and spleen contain only as much antitoxin as can be attributed to their blood content. A mom-

I Berl. klin. Wchnschr., 1896, p. $1186 . \quad$ = Centralbl. f. Bakt., 1902, 31, Orig., p. 208. 
ent's reflection, however, will show that there is a palpable miscalculation involved in this statement. At the time of his test, the fourth day, according to him the blood of the guinea-pig contains about onefifth of the amount originally injected, so that even taking into account the excess of the somatic over the blood immunity as shown above, a simple computation will demonstrate that the blood as compared to the other tissues contains gram for gram so great an excess of antitoxin that no matter how thoroughly the guinea-pig was bled before the experiment, the residue of blood in organs as vascular as these would contain much more antitoxin than the viscera themselves could possibly have. The same objection applies to his statement that no antitoxin at all could be demonstrated in other viscera. In view, therefore, of the strong presumptive evidence that an accumulation of antitoxin occurs in the tissues, it was thought advisable to repeat upon the rabbit experiments somewhat similar to those of Bomstein upon the guinea-pig. It is evident, however, that as long as any quantity of antitoxin is circulating in the blood, such an examination of the tissues is useless, because it is impossible to gauge the quantity of blood in the tissue examined, and consequently one is unable to say what moiety of the toxin-neutralizing power is due to antitoxin in the tissue and not to that in the blood contained in the viscus. Fortunately, this difficulty can be obviated by choosing for the experiment a period at which all antitoxin has disappeared from the blood, but not from the body, such, for instance, as the ${ }^{5} 5^{\text {th }}$ day, which shows the highest somatic immunity of the periods following the disappearance of the antitoxin from the blood. A rabbit weighing $99 \circ$ grams was given $\mathrm{I}, 000$ units intraperitoneally and killed after the lapse of ${ }_{5} 5$ days. At this period we would expect to find about 4 per cent of the immunity afforded by the original injection, but, as will be shown later, the increased size of the injection necessitates raising this figure to somewhat over 5 per cent, so that if uniformly distributed throughout the animal's body each gram of tissue should be able to neutralize at least five guinea-pig minimum lethal doses of diphtheria toxin, the actual neutralizing power being still higher. Pieces of liver, spleen, brain, muscle, and connective tissue were removed, pressed out through sterile cheese-cloth, the liquid mixed with 3 M. L. D. of toxin and injected into a guinea-pig subcutaneously 
after the volume had been made up to 4 c.c. with normal salt solution. About I.5 grams of each tissue were used. . To reduce the danger of contamination these pieces were not weighed each time but were made to correspond in size, as nearly as could be judged, with weighed pieces removed from another animal. The first three tissues were injected separately, the last two together into one guineapig. All four animals died acutely in not over three days and upon postmortem examination showed the typical signs of diphtheric intoxication. The evidence afforded by the experiment appears to demonstrate that antitoxin is not stored as such by the tissues, and while it merely corroborates the evidence of the previous investigators, it does so in a perhaps somewhat less equivocal fashion. Regarding the question of the discrepancy between the blood and the body immunity, it leaves us wholly at sea. We see that the blood does not contain all the antitoxin in the body and therefore the excess is in the tissues, but then how are we to account for the inability of the tissues to neutralize toxin in the test-tube? It might be suggested that the excess of antitoxin is stored in the tissues in some form so altered that it is no longer capable of binding toxin when added to the latter in vitro, but if so it would not be able to neutralize toxin in vivo, and yet such is clearly what it does. The only explanation occurring to me that overcomes this objection is one which assumes that within the living body the cells storing this altered antitoxin respond to the stimulus of the presence of free toxin in the body, as evinced possibly by injury to themselves, by reconverting the antitoxin to its original and chemically active form in order to protect themselves against further damage by the toxin. As to the exact process involved, perhaps the simplest to comprehend would be the occurrence of a change in solubility. When the soluble circulating antitoxin is taken up by the tissues it is precipitated, by an out-salting it may be, and stored in this insoluble form until in response to the stimulus afforded by the presence of toxin, the cells reverse their physicochemical conditions and the antitoxin goes into solution once more. While, unfortunately, such a conception cannot be put to experimental proof, it seems to be the only explanation not incompatible with the facts already determined, and, moreover, is supported by analogy with the similar conception 
of the mechanism of the storing and release of cumulative substances like digitalis.

The next question arising is the manner in which the animal finally rids itself of injected antitoxin. Behring, obtaining evidence of the presence of antitoxin in the milk and urine of passively immunized goats, held that it is eliminated exclusively by the secretions, while, on the other hand, Bulloch, finding no antitoxin in the urine of the ass at a time when the blood content was rapidly decreasing, considers that excretion by the kidneys is not concerned in the process of elimination, and Bomstein, observing that for three or four days the urine of guinea-pigs contained but $\frac{1}{300}$ of the amount of antitoxin then present in the blood, and the viscera, as noted earlier, little or none, suggests that the disappearance is due to some chemical change. These views are thus diametrically opposed, and the importance of the question, it was felt, justified attempting a quantitative examination of the urine of passively immunized rabbits for antitoxin, especially since elimination by the kidneys has been demonstrated (although not quantitatively) in the case of other antitoxins, that of tetanus by Vagedes ${ }^{\mathrm{T}}$ and by Behring, ${ }^{2}$ and that of B. pyocyaneus by Bouchard. ${ }^{3}$ It may be of interest, further, to note that Ehrlich and Wassermann ${ }^{4}$ estimate that the milk contains from $\frac{1}{15}$ to $\frac{1}{30}$ of the blood's content of antitoxin in actively in munized animals.

The technic for this experiment was similar to that of the blood determination already described. Upon the proper day urine was drawn from animals in use for that test by means of a sterile catheter, when necessary levying upon two or more animals to make up the required volume of urine. To the latter was next added diphtheria toxin in such quantity as to neutralize to the desired degree the original blood content of antitoxin, that is, the animal being given four units of antitoxin per cubic centimeter of blood, the urine was titrated to learn what fraction of the four units was present in each cubic centimeter of urine at the particular period under consideration. The toxin-urine

\footnotetext{
× Zischr. f. Hyg., I895, 20, p. 295 .

Infektion u. Desinfektion, Leipzig, 1894 , p. 183 .

3 Compt. rend. Acad. Sci., 1888, 106, p. 1582 .

${ }_{4}$ Ztschr. f. Hyg., 1894, 18, p. 248.
} 
mixtures after being diluted with normal salt solution up to 5 c.c., if below that volume, were injected subcutaneously into guinea-pigs as in the former experiment. In order to economize, tests were omitted on several of the days, but as these did not include the final day, a reasonably accurate idea of the curve of elimination by this channel is afforded.

TABLE 3 .

ExCRETION OF ANTITOXIN BY THE. URINE.

\begin{tabular}{|c|c|c|c|c|}
\hline $\begin{array}{l}\text { Days Interval } \\
\text { between Injec- } \\
\text { tion and } \\
\text { Catheterization }\end{array}$ & $\begin{array}{c}\text { Cubic Centi- } \\
\text { meters } \\
\text { Urine } \\
\text { Injected }\end{array}$ & $\begin{array}{c}\text { M. L. D. } \\
\text { Toxin } \\
\text { Added }\end{array}$ & $\begin{array}{l}\text { Percentage } \\
\text { Neutraliza- } \\
\text { tion }\end{array}$ & $\begin{array}{c}\text { No. Days } \\
\text { Guinea-pig } \\
\text { Survived }\end{array}$ \\
\hline 3 & $\begin{array}{l}0.25 \\
0.5 \\
1 . \\
1 .\end{array}$ & $\begin{array}{l}2.0 \\
2.0 \\
2.6 \\
2.0\end{array}$ & $\begin{array}{l}2 . \\
1 . \\
0.65 \\
0.5\end{array}$ & $\begin{array}{l}1 \\
2 \frac{1}{2} \\
4 \frac{1}{2} \\
6 \frac{1}{2}\end{array}$ \\
\hline\{ & $\begin{array}{l}0.4 \\
0.5 \\
0.5 \\
1 .\end{array}$ & $\begin{array}{l}2.4 \\
2.8 \\
2.0 \\
2.0\end{array}$ & $\begin{array}{l}1.5 \\
1.4 \\
I . \\
0.5\end{array}$ & $\begin{array}{l}3 \frac{1}{2} \\
4 \frac{2}{2} \\
6 \frac{1}{2} \\
+\end{array}$ \\
\hline 7 & 0.5 & 2.8 & 1.4 & $4 \frac{1}{2}$ \\
\hline 9 & $\begin{array}{l}0.5 \\
0.5 \\
x .\end{array}$ & $\begin{array}{l}2.8 \\
2.0 \\
2.0\end{array}$ & $\begin{array}{l}I .4 \\
I . \\
0.5\end{array}$ & $\begin{array}{l}\mathrm{I} \\
2 \frac{1}{2} \\
5\end{array}$ \\
\hline I3 & $\begin{array}{l}4 . \\
5 .\end{array}$ & $\begin{array}{l}2.4 \\
2.0\end{array}$ & $\begin{array}{l}0.25 \\
0.10\end{array}$ & $\begin{array}{l}3 \\
4\end{array}$ \\
\hline $\mathbf{I} 4^{*}$ & 5. & 2. & 0.05 & $2 \frac{1}{2}$ \\
\hline
\end{tabular}

* Eight units per cubic centimeter blood injected.

The results are shown in Table 3 and may be summarized thus:

SUMMARY.

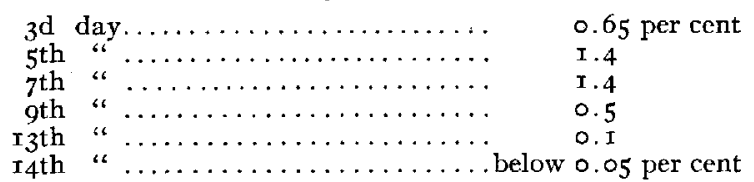

When compared with those in the blood these quantities are seen to be quite insignificant for the first week or so, thus corresponding in general with Bomstein's results, but then, while still decreasing absolutely, the quantity in the urine increases so rapidly relatively to that in the blood that upon the $\mathrm{I} 3^{\text {th }}$ day just preceding its disappearance from the urine, it actually equals the blood's content. Considering it from this standpoint, however, is not justifiable, for it is evident that the only proper way to judge the importance of the rôle played by the kidneys in ridding the system of antitoxin is to 
compare the urinary finding with the decrease in the blood content for the same period, as in this way the extent to which other agencies participate in the process is shown. Another fallacy, although of a minor character, is that involved in the comparison of the urinary content with the actual amount of the decrease in the blood's content, for since the volume of urine secreted in 24 hours under ordinary conditions approximates only about one-fourth that of the blood, substances passing from the latter into the urine will appear to be increased fourfold when equal volumes of the two fluids are compared. Consequently, in order to obtain a correct conception of this process, the urinary findings must be compared with four times the decrease in antitoxin content of the blood for the same period.

In Table 4 there is compiled for the purpose of comparison the quantity of antitoxin present in the blood on each day, the decrease

TABLE 4

\begin{tabular}{|c|c|c|c|c|c|}
\hline $\begin{array}{l}\text { Days after } \\
\text { Injection }\end{array}$ & $\begin{array}{c}\text { Blood's Con- } \\
\text { tent } \\
\text { Percentage }\end{array}$ & $\begin{array}{c}\text { Blood's Loss } \\
\text { from Previous } \\
\text { Day }\end{array}$ & $\begin{array}{l}\text { Urine if } \\
\text { Complete }\end{array}$ & $\begin{array}{c}\text { Percentage } \\
\text { Actually Found }\end{array}$ & $\begin{array}{l}\text { Approximate } \\
\text { Proportion } \\
\text { of Complete }\end{array}$ \\
\hline $\begin{array}{r}1 \\
2 \\
3 \\
4 \\
5 \\
6 \\
7 \\
8 \\
9 \\
10 \\
11 \\
12 \\
13 \\
14 \\
15\end{array}$ & $\begin{array}{l}20 . \\
19 \cdot 5 \\
18.5 \\
16 . \\
12.5 \\
9 \cdot \\
5 . \\
3 . \\
1.7 \\
1.3 \\
0.9 \\
0.4 \\
0.1 \\
0.05 \\
\ldots .05\end{array}$ & $\begin{array}{l}\ldots . \\
0.5 \\
1.5 \\
2.5 \\
3.5 \\
3.5 \\
4.5 \\
2 . \\
1.3 \\
0.4 \\
0.4 \\
0.5 \\
0.3 \\
0.05 \\
0.05\end{array}$ & $\begin{array}{c}\ldots . \\
2 . \\
6 . \\
8 . \\
14 . \\
14 . \\
16 . \\
8 . \\
5.2 \\
1.6 \\
1.6 \\
2 . \\
1.2 \\
0.2 \\
0.2\end{array}$ & $\begin{array}{l}0.65 \\
\mathrm{r} .4 \\
\mathrm{r} .4 \\
0.5\end{array}$ & $\begin{array}{l}\text { II } \\
\text { 10 } \\
9 \\
\text { 10 }\end{array}$ \\
\hline
\end{tabular}

therein for each period, the theoretical complete urinary content, i. e., the amount of antitoxin that would be present in each cubic centimeter of urine if all disappearing from the blood each day were to go into the urine, the actual quantities found in the urine and the proportion borne by the latter to the theoretical complete urinary content. A general survey of the relations of these factors to each other is facilitated by reference to Chart 2 in which these points are presented graphically. The important fact to be noted is that the proportion borne by the actual urinary content of antitoxin and the theoretical complete content varies between 8 and II per cent, with a rough average of to per cent; in other words, approximately to 
per cent only of the decrease in the antitoxin content of the blood goes into the urine, results differing materially from the observations recorded in the literature as cited above. We are, then, justified in concluding that while elimination of the antitoxin by the kidneys is undoubtedly a factor in the mechanism of its disappearance from the body, it is of minor importance and merely subordinate to some more extensive process. What this process may be we can merely

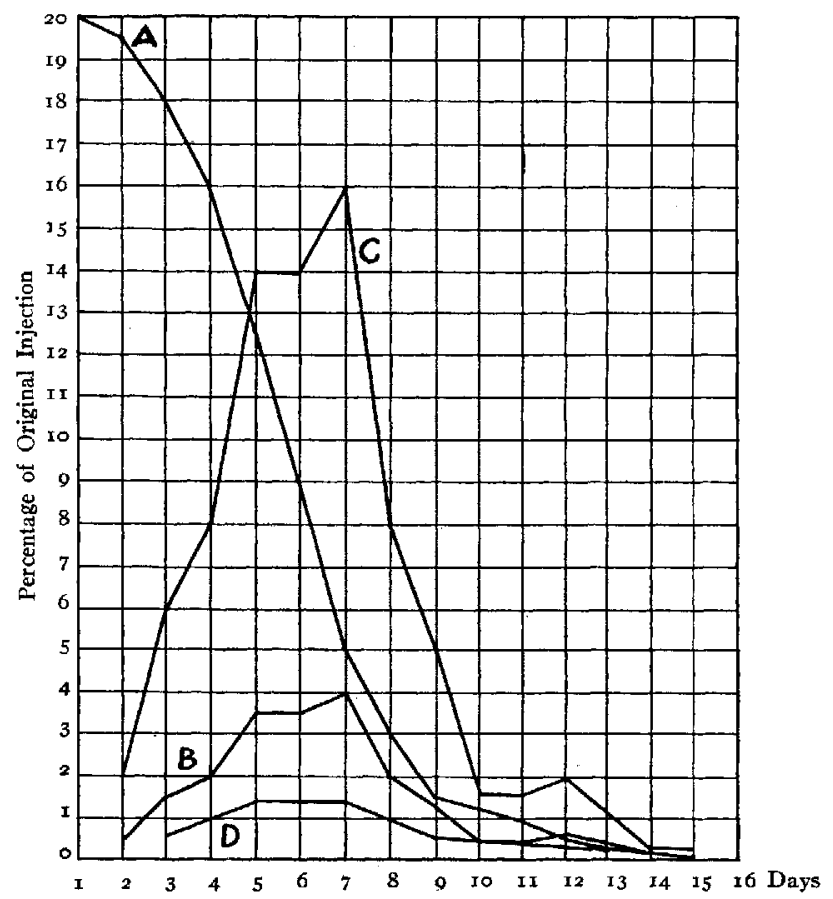

CHART 2.- $A=$ Antitoxin content of Blood; $B$-Decrease in same from previous day; $C$ - Antitoxin content of urine if all of $B$ were to appear in it; $D=$ Antitoxin content of urine as found. Cf. Table 4

surmise at present, but it is highly probable that it is intimately concerned with the peculiar phenomenon of the excess and longer duration of the somatic over the hemic immunity, and it seems not unlikely that the remaining 90 per cent of antitoxin disappearing from the blood is converted into the form in which it is stored. The daily quantitative discrepancy exhibited between the amount missing from the blood and unaccounted for by the urine content with that of the excess of the somatic over the hemic antitoxin content does not by 
any means exclude this possibility, as the rate of disappearance of the chemically inactive form of the antitoxin cannot be determined and may very well be quite different from that of the elimination of the active form from the blood. Concerning the elimination of the chemically inactive form stored in the tissues, the process cannot be initiated by reconversion to the active form, for in that case the antitoxin could be detected in the blood, the rate of this excretion being too rapid to admit of the possibility of the active antibody passing into the blood in quantities too small for detection by biologic methods. This point together with the paucity of antitoxin in the urine in the later stages was considered as sufficient ground for omitting an examination of the urine after the second week. The only alternative, then, is that the tissue cells throw off the antitoxin into the blood in the inactive form in which they have held it and it is then excreted, or else, after storing it for a short time, the cells alter its chemical identity in some way, perhaps, by utilizing it as a food.

It has been shown in an earlier paper ${ }^{\mathrm{I}}$ that in certain animals age is a very important factor in determining the reaction of the body tissues to diphtheria toxin. In view of the fact that antitoxin is used chiefly upon children, the question whether this phenomenon applies to the antitoxin as well as to the toxin, has considerable interest. The matter was investigated by repeating certain of the titrations for somatic immunity upon young rabbits, the original serics having consisted wholly of grown animals. Comparison of the findings (see Table 5) shows that in the rabbit, at least, age is practically of no consequence as a factor in determining the rate of disappearance of injected antitoxin.

Another problem of some practical bearing in connection with the prophylactic use of antidiphtheric serum is how variations in the amount injected affects the extent and duration of the immunity afforded. It is true Behring states that its persistence in the blood of the goat is but slightly increased with the amount given, and Mueller found that in children there was apparently no uniformity between the quantity injected and the duration of the antitoxin in the blood, but inasmuch as neither of these investigators made 
TABLE 5 .

INFLUENCE of AGE upon Elimination of ANtitoxn.

\begin{tabular}{|c|c|c|c|c|c|c|}
\hline$\underset{\text { Interval }}{\text { Days }}$ & Series & $\begin{array}{c}\text { Weight of } \\
\text { Rabbit }\end{array}$ & $\begin{array}{c}\text { Units } \\
\text { Injected }\end{array}$ & $\begin{array}{l}\text { Guinea-pig } \\
\text { M. L. IJ. } \\
\text { of Toxin }\end{array}$ & $\begin{array}{l}\text { Percentage } \\
\text { of Neutrali- } \\
\text { zation }\end{array}$ & $\begin{array}{l}\text { No. Days } \\
\text { Survived }\end{array}$ \\
\hline \multirow{2}{*}{5} & Young \{ & $\begin{array}{l}740 \\
640\end{array}$ & $\begin{array}{l}3.7 \\
3.2\end{array}$ & $\begin{array}{l}66.6 \\
5 I .2\end{array}$ & $\begin{array}{l}18 \\
16\end{array}$ & $\begin{array}{l}3 \\
5\end{array}$ \\
\hline & Adult \{ & $\begin{array}{l}\mathbf{1}, 720 \\
\mathbf{2 , 1 4 0}\end{array}$ & $\begin{array}{r}8.6 \\
\text { To.7 }\end{array}$ & $\begin{array}{l}137.6 \\
160.5\end{array}$ & $\begin{array}{l}16 \\
15\end{array}$ & $\begin{array}{l}4 \frac{1}{2} \\
5 \frac{1}{2}\end{array}$ \\
\hline \multirow[b]{2}{*}{7} & Young & 720 & 3.6 & 50.4 & 12 & $3 \frac{1}{2}$ \\
\hline & Adult & $\begin{array}{l}2,390 \\
2,085\end{array}$ & $\begin{array}{l}\text { II.95 } \\
10.42\end{array}$ & $\begin{array}{r}155.35 \\
125.05\end{array}$ & $\begin{array}{l}13 \\
12\end{array}$ & $4 \frac{1}{2}$ \\
\hline
\end{tabular}

systematic quantitative determinations, and further, since, as shown above, the amount of antitoxin in the blood is not a criterion of the extent of the general immunity, the following experiment was undertaken. A series of rabbits were given antitoxin injections in amounts of $\mathrm{I}, 2,5,10,20,5 \circ$, and 100 times the quantity used in determining the somatic immunity (five units per kilo of body weight), and after the lapse of 15 days the residue of the original immunity persisting in each case was determined by biologic titration as before. The results of the experiment recorded in Table 6 seem to show clearly,

TABLE 6.

Ratio between Amount of Antitoxin Injected and Rate of Eimination.

\begin{tabular}{|c|c|c|c|c|c|}
\hline $\begin{array}{l}\text { Units per } \\
\text { c.c. Blood }\end{array}$ & $\begin{array}{c}\text { Weight of } \\
\text { Rabbit }\end{array}$ & $\begin{array}{l}\text { Units Anti- } \\
\text { toxin } \\
\text { Injected }\end{array}$ & $\begin{array}{c}\text { Guinea-pig } \\
\text { M. L. D. of } \\
\text { Toxin Injected }\end{array}$ & $\begin{array}{c}\text { Percentage of } \\
\text { Neutralization } \\
\text { of Antitoxin }\end{array}$ & $\begin{array}{c}\text { No. Days } \\
\text { Rabbit } \\
\text { Survived }\end{array}$ \\
\hline 5 & $I, \infty 00$ & 5. & 20. & 4. & $4 \frac{1}{2}$ \\
\hline Io & $\begin{array}{r}I, 320 \\
945\end{array}$ & $\begin{array}{l}13.2 \\
9.45\end{array}$ & $\begin{array}{l}52.8 \\
37.8\end{array}$ & $\begin{array}{l}4 . \\
4 .\end{array}$ & $\begin{array}{l}5 \frac{1}{2} \\
4\end{array}$ \\
\hline 25 & $\mathrm{I}, 6 \times 0$ & 40.25 & 161.0 & 4. & $4 \frac{1}{2}$ \\
\hline 50 & $\begin{array}{l}1,830 \\
1,515 \\
1,170\end{array}$ & $\begin{array}{l}91 \cdot 5 \\
75 \cdot 75 \\
58.5\end{array}$ & $\begin{array}{l}4 \mathrm{II} \cdot 75 \\
3 \mathrm{I} 8.15 \\
234 .\end{array}$ & $\begin{array}{l}4.5 \\
4.2 \\
4 .\end{array}$ & $\begin{array}{l}2 \frac{1}{2} \\
5 \\
6 \frac{1}{2}\end{array}$ \\
\hline 100 & $\begin{array}{r}1,700 \\
980\end{array}$ & $\begin{array}{r}170 . \\
98 .\end{array}$ & $\begin{array}{l}782 . \\
431.2\end{array}$ & $\begin{array}{l}4.6 \\
4.4\end{array}$ & $\begin{array}{l}3 \\
5\end{array}$ \\
\hline 250 & $\begin{array}{l}1,205 \\
1,265 \\
1,445\end{array}$ & $\begin{array}{l}301.25 \\
316.25 \\
361.25\end{array}$ & $\begin{array}{l}\mathrm{I}, 506.25 \\
\mathrm{I}, 486.4 \\
\mathrm{I}, 625.6\end{array}$ & $\begin{array}{l}5 . \\
4 \cdot 7 \\
4 \cdot 5\end{array}$ & $\begin{array}{l}3 \frac{3}{3} \\
4 \frac{3}{2} \\
6\end{array}$ \\
\hline 500 & $\begin{array}{r}\mathbf{x}, 025 \\
920 \\
\mathbf{r}, 900\end{array}$ & $\begin{array}{l}512.5 \\
460 . \\
545\end{array}$ & $\begin{array}{l}2,613 \cdot 75 \\
2,254 \cdot \\
2,561 \cdot 5\end{array}$ & $\begin{array}{l}5.1 \\
4 \cdot 9 \\
4.7\end{array}$ & $\begin{array}{l}3 \\
5 \frac{1}{2} \\
7 \frac{1}{2}\end{array}$ \\
\hline
\end{tabular}

that upon increasing the amount of antitoxin given, the quantity eliminated is increased pari passu; indeed, not until the amount injected has been increased tenfold is there the slightest appreciable 
change in the rate of disappearance, and even with one hundred times the amount of the original injection this rate is so nearly the same that on the I $5^{\text {th }}$ day there is a difference of but a trifle over I per cent in the ratios borne by the residues in the body to the original injections. While, therefore, at any given period the actual extent of the immunity is greater with larger injections of antitoxin, since the elimination is correspondingly accelerated, the duration of the immunity is scarcely lengthened. A short experiment was performed to verify this deduction. Reference to Table I shows that with an injection of 20 units of antitoxin per kilo of weight ( 0.4 units per gram of blood) no exaltation of the natural immunity could be demonstrated after the 23 d day. Another animal was now given an injection of 500 units per kilo of weight (Io units per gram of blood), or 25 times the previous quantity, and tested as before upon the 26th day, when it was found that antitoxin was present, if at all, in a quantity of less than $\frac{1}{2} 0$ of $I$ per cent.

Objections may be raised to the results obtained here on the ground that the $\mathrm{L}+$ dose of toxin rather than the M. L. D. should have been used in testing for antitoxin, as it is more accurate and reliable because less affected by the proportion of toxoids in the filtrate. This, of course is quite true, but in this particular study I do not think accuracy was sacrificed by the choice of the quantity-standard of toxin. In the first place, in all the above experiments (excepting only those recorded in Table 5) the same toxin was $\epsilon$ mployed, and it seems but reasonable to assume that the correction curve that could be applied to it, because of the gradually increasing toxoid content, is less complicated and more uniform than that applying to a number of toxins employed at the $\mathrm{L}+$ dose, if that had been the case, for the proportion of toxoid in the binding-units with affinities between the $\mathrm{L}^{\circ}$ and the $\mathrm{L}+$ doses likewise is different in each filtrate. In the second place, a doublestandard value for the neutralization is avoided. While the $L+$ dose could have been used in ascertaining the antitoxin content of the blood, since that was tested upon guinea-pigs, it naturally could not have been used in determining the somatic immunity, for the $\mathbf{L}+$ is purely a guinea-pig dose and cannot be used upon rabbits because the amount of toxin between the $\mathrm{L}^{\circ}$ and $\mathrm{L}+$ doses, while fatal to guinea-pigs, is by no means so to rabbits. It would therefore be necessary to establish 
a "rabbit $\mathrm{L}+$ dose" for the somatic immunity titration while using a "guinea-pig $\mathrm{L}+$ dose" for the hemic immunity, and we do not know in such a case that we are employing comparable standards. On the other hand, the use solely of the guinea-pig M. L. D., as in these experiments, obviates this uncertainty and makes it possible to consider everything in terms of guinea-pig resistance, a surprisingly constant quantity. This security, I believe, is of great importance in these experiments because of the necessity of comparing reaction in two different species of animals. Then, with the M. L. D. very much smaller quantities of antitoxin can be detected than with the $\mathrm{L}+$ dose. This not merely permits of following the history of the antitoxin more closely, but removes the necessity of injecting amounts of both antitoxin so large that they would, it is likely, provoke extraneous reactions on the part of the animal tending to obscure the point at issue, and not improbably interfere seriously with the accuracy of the experiment. Finally, to learn how great a difference, if any, might occur between titrations based on the $\mathrm{L}+$ dose and those on the M. L. D. a series of parallel determinations with the former were made upon the antitoxin content of the blood. The results obtained, shown in Table 7 , are not exactly the same, it is true, as those secured by means of the M. L. D. (see Table 8 for the comparison), but they are close enough

TABLE 7.

Tirration with L + DOSE.

\begin{tabular}{|c|c|c|c|c|c|c|}
\hline $\begin{array}{c}\text { Days } \\
\text { Interval }\end{array}$ & $\begin{array}{l}\text { Weight of } \\
\text { Rabbit }\end{array}$ & $\begin{array}{c}\text { Units } \\
\text { Antitoxin } \\
\text { Injected }\end{array}$ & $\begin{array}{c}\text { Units } \\
\text { per Gram } \\
\text { Weight }\end{array}$ & $\begin{array}{l}\text { Cubic Centi- } \\
\text { meters Blood } \\
\text { Added to } \\
\mathbf{L}+\text { Dose }\end{array}$ & $\begin{array}{l}\text { Percentage } \\
\text { of Neu- } \\
\text { tralization }\end{array}$ & $\begin{array}{l}\text { No. Days } \\
\text { Guinea-pig } \\
\text { Survived }\end{array}$ \\
\hline 2\{ & $\begin{array}{l}I, 580 \\
r, 760 \\
I, 790\end{array}$ & $\begin{array}{l}632 \\
704 \\
706\end{array}$ & $\begin{array}{l}8 \\
8 \\
8\end{array}$ & $\begin{array}{l}0.5 \\
0.625 \\
0.7\end{array}$ & $\begin{array}{l}25 \\
20 \\
18\end{array}$ & $\begin{array}{l}\mathrm{I} \\
4 \\
+\end{array}$ \\
\hline\{ & $\begin{array}{l}1,820 \\
1,860 \\
1,800\end{array}$ & $\begin{array}{l}728 \\
744 \\
706\end{array}$ & $\begin{array}{l}8 \\
8 \\
8\end{array}$ & $\begin{array}{l}0.78 \\
0.80 \\
0.96\end{array}$ & $\begin{array}{l}16 \\
\mathrm{r4} \\
\mathrm{I3}\end{array}$ & $\begin{array}{l}1 \frac{1}{2} \\
3 \frac{1}{2} \\
5 \frac{1}{2}\end{array}$ \\
\hline\{ & $\begin{array}{l}2,000 \\
1,450\end{array}$ & $\begin{array}{l}800 \\
584\end{array}$ & $\begin{array}{l}8 \\
8\end{array}$ & $\begin{array}{l}1.78 \\
2.5\end{array}$ & $\begin{array}{l}7 \\
5\end{array}$ & $\begin{array}{l}3 \\
7 \frac{1}{2}\end{array}$ \\
\hline
\end{tabular}

TABLE 8.

Comparison of Results wite M. L. D. and with L+ Dose as Standards.

\begin{tabular}{c|c|c|c}
\hline $\begin{array}{c}\text { Days } \\
\text { Interval }\end{array}$ & $\begin{array}{c}\text { Result with } \\
\text { M. L. D. }\end{array}$ & $\begin{array}{c}\text { Result with } \\
\text { L+ Dose }\end{array}$ & Difference \\
\hline 2 & $19.5 \%$ & $20 \%$ & $+0.5 \%$ \\
4 & 16 & 14 & $\begin{array}{l}2.0 \\
+1.0\end{array}$ \\
\hline
\end{tabular}


to justify confidence that the curves determined by the two standards are practically the same.

The conclusions that may be drawn from the foregoing are:

I. In passive immunization with diphtheria antitoxin, the degree of protection afforded is always in excess of the protection as calculated from the amount of antitoxin in the blood.

2. Free antitoxin disappears from the blood before immunity is wholly lost by the organism.

3. Diphtheria antitoxin is eliminated by the kidneys, though to but a minor degree.

4. The duration of the protection conferred is practically independent of the quantity of antitoxin administered and of the age of the animal.

The writer wishes to express his thanks to Professor Edwin O. Jordan for advice and suggestions during the course of this study. 